\title{
Distinct features of adaptive and productive potential of prospective pear varieties
}

\author{
Svetlana Rezviakova ${ }^{1, *}$, Aleksandr Gurin ${ }^{1}$, and Nikolai Revin ${ }^{1}$ \\ ${ }^{1}$ Oryol State Agricultural University named after N.V. Parakhin, Faculty of Agribusiness and Ecology, Department of Plant Protection \\ and Ecotoxicology, Oryol, Russia
}

\begin{abstract}
The goal of the research is to identify the most productive and environmentally sustainable varieties of pear in the conditions of the Central Black Earth region of Russia. The research was carried out from 2015 to 2017 in the Oryol Oblast on leached black earth. The average humus content in the arable layer was $6.0-6.5 \%$, phosphorus $-21-27 \mathrm{mg} / 100 \mathrm{~g}$, potassium $-12-15 \mathrm{mg} / 100 \mathrm{~g}$. Soil acidity was $5.7-6.1$. The thickness of the humus horizon was $40-75 \mathrm{~cm}$. The degree of saturation of the bases was within $91 \%$. Climate in the region is moderate-continental, heat is sufficient for the normal growth and development of fruit plants. The trees were planted in 2004; the scheme of planting was $6 \times 4 \mathrm{~m}$. The stock was seedlings of common pear. Accounting was conducted using the "Program and method of studying fruit, berry and nut crop varieties" (Oryol, 1999). The varieties Pamiati Yakovleva and Annushka are characterized by a restrained growth force $-3.5-3.8 \mathrm{~m}$. In the natural climatic conditions of the Oryol Oblast, the Annushka and Velesa varieties are considered hardy, the Rossoshanskaya krupnaya and Svetlyanka - medium-hardy. Varieties Annushka and Velesa are quite resistant to the pathogens of scab, brown and white spotting - the average score for damage to fruits and leaves did not exceed 1.5. On average, for 3 years the yield of the Rossoshanskaya krupnaya pear variety was at the level of the zoned control variety Pamiati Yakovleva. Yields were 112.2 and 108.3 centners per hectare, respectively. The yield of the Annushka variety was 7.5 centners per hectare, or $6.7 \%$ higher than that of the control variety.
\end{abstract}

\section{Introduction}

Gardening is the most important branch of the agroindustrial complex of the Russian Federation and many other countries. Its main purpose is producing and supplying population with fruits and berries, which are sources of vitamins, mineral and organic substances that play the most important physiological role in the metabolism of the human body [1-7]. Which is why it is no accident that a large and constant attention is paid to the further development of the industry [8-13]. In particular, the program "Revival of Horticulture of Russia" developed by the Ministry of Agriculture of the Russian Federation and the Russian Academy of Agriculture, aims to expand the area under perennial plantings to 1.5 million hectares in the coming years, and to bring the production of fruits and berries to 10.6 million tons. At the same time, the yield of seed crops should be at least 120 centners per hectare.

Pear, as a fruit breed, is known since prehistoric times and now grows in a variety of areas of the world. The spread of pear trees is second only to apple trees $[14,15]$. This is due to the shortcomings of the existing varieties - significant susceptibility to scab, tall trees and late entry into the fruiting stage. However, pears regularly yield significant harvests. Organoleptic qualities of its dessert varieties are much better than those of best varieties of apples [16-20]. Late (winter) varieties have fruits that tolerate transportation well and can be stored for a long time.

Since the pear is less hardy and more heat-loving than an apple tree, its share in the structure of the gardens of the middle garden area of Russia is much lower [21-23].

The goal of the research is to identify the most productive and environmentally sustainable varieties of pear in the conditions of the Central Black Earth region of Russia.

\section{Materials and methods}

The research was conducted during 2015-2017 in the Oryol Oblast on the leached black earth. The average humus content in the arable layer was $6.0-6.5 \%$, phosphorus - 21-27 $\mathrm{mg} / 100 \mathrm{~g}$, potassium - 12-15 $\mathrm{mg} / 100 \mathrm{~g}$. Soil acidity was $5.7-6.1$. The thickness of the humus horizon was $40-75 \mathrm{~cm}$. The degree of saturation of the bases was within $91 \%$.

The climate in that region is moderate-continental and is characterized by uneven distribution of precipitation, temperature and humidity during the seasons. The growing season lasts for 175-185 days, precipitation is distributed unevenly, and often, during the most crucial growing season (second half of April

\footnotetext{
* Corresponding author: lana8545@yandex.ru
} 
and May) there are droughts, accompanied by southeasterly winds; the average annual air temperature is $4.5^{\circ} \mathrm{C}$, so there is enough heat for the normal growth and development of fruit plants.

The absolute minimum temperature of the air in severe winters reaches $-40{ }^{\circ} \mathrm{C}$, and on the surface of snow it can reach $-42--44^{\circ} \mathrm{C}$. Maximum temperature is fixed at $36-38^{\circ} \mathrm{C}$. The amount of effective temperatures above $5{ }^{\circ} \mathrm{C}$ is $1750{ }^{\circ} \mathrm{C}$. The amount of precipitation on average for the year is $571 \mathrm{~mm}$. The average duration of the frost-free period is 146 days. The average height of the snow cover is $22-24 \mathrm{~cm}$. Snow cover holds for no more than 3.5 months.

The objects of research were varieties of pear of domestic breeding in the fruiting stage. The trees were planted in 2004, the scheme of planting was $6 \times 4 \mathrm{~m}$. The stock was seedlings of common pear.

\subsection{Short descriptions of the varieties}

\subsubsection{Annushka}

This autumn variety with fruits of dessert quality has been bred by the Institute of Fruit Crop Breeding. The variety is designed by E.N. Sedov, A.G. Kuznetsova, N.G. Krasova, and N.M. Glazova. The variety is under State testing since 2002.

Advantages: early maturity, high yield, dessert taste of fruits.

\subsubsection{Pamiati Yakovleva (control)}

This early autumn variety was obtained in the Institute of Genetics and Breeding of Fruit Plants named after I.V. Michurin and in Michurin Agrouniversity by P.N. Yakovlev, S.P. Yakovlev, Y.S. Nesterov, and R.M. Korshikova.

Advantages: small trees, early maturity, high hardiness, self-fertility, resistance to scabs.

Disadvantages: with age and with abundant fruiting there may appear some unevenness of fruits, the presence of sclerenchyma cells.

\subsubsection{Svetlyanka}

Svetlyanka is an early autumn variety. It originates from the NSU Institute of Genetics and Breeding of Fruit Plants by I.V. Michurin. Authors of the variety are P.N. Yakovlev, S.P. Yakovlev, and A.P. Gribanovsky.

Advantages: good taste of fruits, complex resistance to diseases, when processed, the resulting products are of high quality.

Disadvantages: during the thickening of the crown, the fruits get smaller, with long-term storage surface rotting may appear on some of the fruit.

\subsubsection{Selyanka (Rossoshanskaya krupnaya)}

This late-autumn variety is made by Rossoshan Zonal Experimental Station of Horticulture by A.M.
Ulyanischeva and O.V. Ryazantseva. It has been zoned in the Central Black Earth region.

Advantages: relatively high for the south of the CBE region hardiness.

Disadvantages: susceptibility of leaves to septoriosis, severe damage by insects of the Psyllidae family.

\subsubsection{Velesa (Doch Otlichnoi)}

Velesa is an autumn variety designed in the FSBSI AllRussian Horticultural Institute for Breeding, Agrotechnology and Nursery by Y.A. Petrov and N.V. Efimova. Included in the State Registry (zoned) in 2001.

Advantages: significant ecological stability, high regular yields, prominent commercial and consumer qualities of fruits.

Disadvantages: with an abundant harvest the fruit can get smaller.

Accounting was conducted according to the "Program and method of studying fruit, berry and nut crop varieties" [24].

Statistical processing of the results of the studies presented in tables 1, 3 and 4 was done using the method of dispersion analysis [25].

\section{Results}

\subsection{Evaluation of pear varieties by their biometric indicators}

Determination of tree feeding area, as well as the conditions for agro-technical care and fruit gathering, are largely related to the size and shape of the crown. The size of the trees, the strength of growth and the nature of branching depends mainly on the stock, the grafted variety and the conditions of growth. P.G. Shitt wrote: "The strength and rhythm of growth processes in fruit trees is constantly influenced by the conditions of the external environment. The nature of the impact of these conditions on the plant at certain periods can be judged by the development of vegetative and generative growths of their structure and placement in the crowns of trees. The long-term impact of some permanent factor leaves an imprint on the habitus of tree growth and fruiting." Thus, trees are, as it were, objective "recorders" of the influence of external conditions on growth and development.

The resulting experimental material indicates that the studied varieties of pears vary in height, which is within 3.5-4.9 m. The trees of Svetlyanka, Rossoshanskaya krupnaya and Velesa varieties were the tallest, ranging within 4.6-4.9 m, the lowest height was noted for the varieties Pamiati Yakovleva and Annushka-3.5-3.8 m. 
Table 1. Biometric indicators of pear trees grafted on the seedlings of common pear.

\begin{tabular}{|c|c|c|c|c|}
\hline \multirow[b]{2}{*}{ Variety } & \multirow{2}{*}{$\begin{array}{c}\text { Height of } \\
\text { the tree, } \\
\text { m }\end{array}$} & \multirow{2}{*}{\begin{tabular}{|c} 
The \\
diameter of \\
the stamp, \\
cm
\end{tabular}} & \multicolumn{2}{|c|}{ Crown size, $\mathbf{m}$} \\
\hline & & & $\begin{array}{l}\text { Along } \\
\text { the row }\end{array}$ & $\begin{array}{l}\text { Across } \\
\text { the row }\end{array}$ \\
\hline Svetlyanka & 4.9 & 16.3 & 3.6 & 3.5 \\
\hline $\begin{array}{c}\text { Rossoshanskaya } \\
\text { krupnaya }\end{array}$ & 4.7 & 15.2 & 3.9 & 3.7 \\
\hline Velesa & 4.6 & 14.6 & 4.1 & 4.0 \\
\hline Annushka & 3.8 & 11.5 & 3.8 & 3.6 \\
\hline $\begin{array}{c}\text { Pamiati } \\
\text { Yakovleva } \\
\text { (control) }\end{array}$ & 3.5 & 12.8 & 3.5 & 3.3 \\
\hline $\begin{array}{c}\text { Least } \\
\text { Significant } \\
\text { Difference } 05\end{array}$ & 0.80 & 1.52 & 0.46 & - \\
\hline
\end{tabular}

The stamp of the tree is important for the growth and development of the above-ground part of the plant, as it moves nutrients and water from the soil to the aboveground organs, as well as products of photosynthesis to the roots. The state of the stamp largely determines the development of the tree crown, and its growth depends on both the placement scheme and the biological features of the variety. The stamp is an indicator of the condition and potential development of the growth processes of fruit plants. The diameter of the stamp in the trees of the studied varieties was $11.5-16.3 \mathrm{~cm}$. The Pamiati Yakovleva and Annushka varieties are distinguished by restrained growth power, the remaining varieties are medium-growing. As for the size of the crown, as can be seen from the results obtained, the trees of the studied varieties almost completely mastered the area allocated to them $-4 \mathrm{~m}$ in a row. Velesa and Rossoshanskaya krupnaya varieties had the most spreading crown, while it was more compressed in trees of varieties Annushka, Svetlyanka and Pamiati Yakovleva.

\subsection{Evaluation of pear varieties by their hardiness}

During the years of research, winters were warm. The amount of negative air temperature was $427.8-543.1^{\circ} \mathrm{C}$. The lowest air temperature of $-27.2^{\circ} \mathrm{C}$ was recorded in January 2015; during the winters of 2015/16 and 2016/2017 the air temperatures were dropping to $22.6{ }^{\circ} \mathrm{C}$ and $-21.2^{\circ} \mathrm{C}$ respectively, and on the surface of snow - to $-25.4{ }^{\circ} \mathrm{C}$ and $-22.5^{\circ} \mathrm{C}$. Such frosts are not critical for pears. However, if during the second half of winter, when the trees are in forced rest, the frosts are preceded with thaws, some damage occurs. So, in the studied pear varieties we have noted freezing of the bark, wood, and branches of up to $1.2-1.4$ points (table 2 ). The control variety Pamiati Yakovleva established high resistance to the sum of stress factors in the winter period. Over the years of research, no frost damage was noted for this variety.
Table 2. Frost damage to pear trees in the field.

\begin{tabular}{|c|c|c|c|c|}
\hline \multirow{2}{*}{ Variety } & \multicolumn{4}{|c|}{ Maximum damage score } \\
\cline { 2 - 5 } & Bark & Wood & Branches & Shared \\
\hline $\begin{array}{c}\text { Pamiati Yakovleva } \\
\text { (control) }\end{array}$ & 0.0 & 0.0 & 0.0 & 0.0 \\
\hline Velesa & 0.8 & 0.8 & 0.8 & 0.8 \\
\hline $\begin{array}{c}\text { Annushka } \\
\text { Rossoshanskaya } \\
\text { krupnaya }\end{array}$ & 1.2 & 0.6 & 1.0 & 1.0 \\
\hline Svetlyanka & 1.4 & 1.2 & 1.2 & 1.2 \\
\hline
\end{tabular}

In general, in the Oryol Oblast, the varieties of Annushka and Velesa are considered hardy, Rossoshanskaya krupnaya and Svetlyanka - mediumhardy.

\subsection{Evaluation of pear varieties on resistance to fungal diseases}

Resistance to diseases is a varietal feature subject to the influence of environmental conditions and the racial composition of pathogens. The main diseases of the pear include scab, brown leaf spot or phyllostic and white leaf spot or septoria (Program and method of studying fruit, berry and nut crop varieties, 1999).

Scab is the most common disease of seed crops. The pathogens are the teleomorph Venturia inaequalis and Venturia pirina fungi that affect leaves, flowers, fruits, and sometimes shoots. On leaves and fruits, roundish or blurry, sometimes diffuse, spots appear with a greenisholive velvety bloom of sporulation of the fungus. Subsequently, with severe damage, the spots turn brown, necrotic. Small puffs form on the shoots of the pear, then the bark cracks and peels off, sores appear, and soon the shoot dies.

The brown spotting of pear leaves is caused by Phyllosticta pirina fungi. Spots appear on the leaves, usually brown, round or irregular in shape, often merging. The disease emerges at the beginning or middle of summer, on sufficiently developed leaves and then progresses until the fall. This disease leads to a significant weakening of the assimilation apparatus, and with strong development - to premature leaf fall. The disease develops mainly as a secondary phenomenon on the background of burns from the use of fungicides or insecticides, damage by insects, hail, etc.

The causative agent of the white spotting of pear leaves (septoriosis) is the pycnidia-producing fungus Septoria piricola (its teleomorph is Mycosphaerella sentina). Appearing in June-July, by August, the disease reaches mass development and often leads to premature fall of leaves, especially on old trees. At first, small, rounded, white spots with a dark brown border appear, 1 to $5 \mathrm{~mm}$ in diameter. In the central part, fungal pycnidia form over time in the form of clearly visible black dots.

In the middle gardening area, the most dangerous and harmful pear disease is scab. Fruits and leaves of the control variety Pamiati Yakovleva were damaged only slightly, scoring $0.5-0.7$ points (table 3 ). Fruits of the Velesa variety remained completely healthy, while its leaves were damaged, scoring 1. 
Table 3. Resistance of pear varieties to fungal diseases (average for 3 years).

\begin{tabular}{|c|c|c|c|c|}
\hline \multirow{2}{*}{ Variety } & \multicolumn{4}{|c|}{ Average damage score } \\
\cline { 2 - 5 } & \multicolumn{2}{|c|}{ Scab } & $\begin{array}{c}\text { Brown } \\
\text { spotting }\end{array}$ & $\begin{array}{c}\text { White } \\
\text { spotting } \\
\text { (septorosis) }\end{array}$ \\
\cline { 2 - 5 } & Fruits & Leaves & Leaves & Leaves \\
\hline $\begin{array}{c}\text { Pamiati Yakovleva } \\
\text { (control) }\end{array}$ & 0.5 & 0.7 & 1.1 & 1.1 \\
\hline Velesa & 0.0 & 1.0 & 1.3 & 1.3 \\
\hline $\begin{array}{c}\text { Rossoshanskaya } \\
\text { krupnaya }\end{array}$ & 1.0 & 1.5 & 1.9 & 1.7 \\
\hline Annushka & 0.8 & 1.0 & 1.5 & 1.4 \\
\hline Svetlyanka & 1.3 & 1.5 & 1.5 & 1.9 \\
\hline $\begin{array}{c}\text { Least Significant } \\
\text { Difference } 05\end{array}$ & 0.47 & 0.49 & 0.50 & 0.42 \\
\hline
\end{tabular}

The damage done to the Annushka variety was on the level of the one done to the control -0.8 to its fruit and 1.0 to its leaves. For all the studied varieties the damage done to their leaves by scab was $0.5-1.0$ points higher than to their fruit.

The leaves of the control variety were affected by brown spotting and septoriosis (white spotting), scoring 1.1 points. To a moderate degree (1.9 points), the leaves of the Rossoshanskaya krupnaya pear variety were affected by brown spotting. In the varieties Velesa, Annushka and Svetlyanka, the development of this disease was found to be 1.3 to 1.5 points, approximately at the control grade level. By resistance to white spotting, Velesa and Annushka are not inferior to the Pamiati Yakovleva. The maximum damage score was revealed for the Rossoshanskaya krupnaya and Svetlyanka varieties - 1.7-1.9. Consequently, the new varieties of the pear Velesa and Annushka are quite resistant to the pathogens of the main diseases caused by microscopic fungi. Varieties Rossoshanskaya krupnaya and Svetlyanka are slightly inferior to the Pamiati Yakovleva by the studied characteristics.

\subsection{Evaluation of pear varieties by yield}

The harvest records made it possible to establish that on average for 3 years the Rossoshanskaya krupnaya pear variety is at the level of control one (table 4).

Table 4. Yields of new varieties of pears (average for three years.

\begin{tabular}{|c|c|c|c|}
\hline Variety & $\begin{array}{c}\text { Yields, } \\
\text { c/ha }\end{array}$ & $\begin{array}{c}\text { Relative to } \\
\text { control, c/ha }\end{array}$ & $\begin{array}{c}\text { Relative to } \\
\text { control, \% }\end{array}$ \\
\hline $\begin{array}{c}\text { Pamiati Yakovleva } \\
\text { (control) }\end{array}$ & 112.2 & - & - \\
\hline Velesa & 101.8 & -10.4 & -9.3 \\
\hline Svetlyanka & 95.9 & -16.3 & -14.6 \\
\hline $\begin{array}{c}\text { Rossoshanskaya } \\
\text { krupnaya }\end{array}$ & 108.3 & -3.9 & -3.5 \\
\hline Annushka & 119.7 & 7.5 & 6.7 \\
\hline $\begin{array}{c}\text { Least Significant } \\
\text { Difference } 05\end{array}$ & 5.82 & - & - \\
\hline
\end{tabular}

The yield was 112.2 and 108.3 centners per hectare, respectively. The increase for Annushka variety was
$7.5 \mathrm{c} /$ ha or $6.7 \%$. Pear varieties Velesa and Svetlyanka are inferior in yields by 9.3 and $14.6 \%$ respectively to the zoned Pamiati Yakovleva variety.

\section{Conclusion}

1. The trees of Velesa and Rossoshanskaya krupnaya varieties have the most sprawling crowns, Annushka, Svetlyanka and Pamiati Yakovleva - more compressed crowns.

2. In the Orlovsk region, the Anushka and Velesa pear varieties are considered hardy, Rossoshanskaya krupnaya and Svetlyanka - medium-hardy.

3. New varieties of pear Velesa and Annushka are quite resistant to the pathogens of the main fungal diseases - scab, brown and white spotting.

4. The Annushka pear variety in the natural climatic conditions of the Orlov region during the years of research produced stable yields at the level and above the control zoned variety Pamiati Yakovleva, with the yields of Rossoshanskaya krupnaya being at the level of the control variety.

\section{References}

[1] A.G. Gurin, S.A. Plygun, V.I. Averin, Increasing the production potential of healthy planting material of original varieties of fruit and ornamental crops, Bulletin of the Oryol State Agrarian University, 3, 18, 55-56 (2009).

[2] L.V. Levshakov, O.A. Smirenin, Values of foliar fertilization for optimization of the integrated nutrition system of a young apple orchard, Bulletin of the Kursk State Agricultural Academy, 9, 30-38 (2019).

[3] S.V. Rezvyakova, A.G. Gurin, N.Yu. Revin, E.S. Rezvyakova, Techniques for increasing the productivity and environmental sustainability of plants on a biological basis, A monograph, FSBEI HE Oryol SAU, Oryol, 167 (2017).

[4] R.A. Sagirova, The current state and prospects for the development of industrial gardening in the Irkutsk region, Bulletin of the Irkutsk State Agricultural Academy, 89, 23-29 (2018).

[5] I.V. Kazakov, S.N. Evdokimenko, D.N. Skovorodnikov, Breeding primocane raspberries in Russia, Acta Horticulturae, 946, 167-170 (2012).

[6] E.N. Sedov, G.A. Sedysheva, Z.M. Serova, S.A. Korneeva, Genome constructing opens new opportunities in apple, Malus domestica Borkh, breeding for scab immunity, fruit qality and easy orcharding, Agricultural Biology, 51, 411-418 (2016).

[7] S.K. Yadav, Cold stress tolerance mechanisms in plants, Agron. Sustain. Dev., 30, 515-527 (2010).

[8] V.S. Dokukin, A.G. Gurin, Reserves of increased production of berries in Russia, Gardening and Viticulture, 5-6, 2 (1997). 
[9] L.V. Levshakov, N.V. Volobueva, S.G. Yadykin, A.A. Podstrela, Technological aspects of obtaining high-quality planting material of apple trees in the conditions of the Central Black Earth Region, Bulletin of the Kursk State Agricultural Academy, 9, 49-56 (2018).

[10] M.A. Rachenko, A.M. Shigarova, T.E. Putilina, E.I. Rachenko, Prospects for industrial gardening in the South Cisbaikalia, Bulletin of the RAAS, 3, 18-21 (2013).

[11] E.N. Sedov, M.A. Makarkina, G.A. Sedysheva, Z.M. Serova, 60 year bred conveyor of apple varieties, their resistance to scab and biochemical characteristics of fruits, Agricultural Biology, 50, 637-640 (2015).

[12] M. Wisniewski, A. Nassuth, C. Teulieres, C. Marque, J. Rowland, P.B. Cao, A. Brown, Genomics of cold hardiness in woody plants, Critical reviews in Plant Sciences, 33, 2-3, 92124 (2014).

[13] Z. Xin, J. Browse, Cold comfort farm: the acclimation of plants to freezing temperatures, Plant, Cell and Environment, 23, 893-902 (2000).

[14] I.A. Bandurko, V.M. Kotov, Assessment of the varietal collection of the pear of the Maikop OS VIR for hardiness, Modern gardening, 2 (2013).

[15] P.G. Luchkov, R.Kh. Kudaev, A.G. Gurin, The reaction of fruit crops to growing conditions of reclaimed slopes, Bulletin of the Oryol State Agrarian University, 3, 6, 25-28 (2007).

[16] M.A. Rachenko, E.I. Rachenko, Yu.S. Korzinnikov, Studying the adaptability of apple varieties in the Cisbaikalia, Bulletin of the RAAS, 4, 36-40 (2011).

[17] S.V. Rezvyakova, Actual issues of improving the assortment and technology of pear cultivation, Horticulture and Viticulture, 1, 21-23 (1998).

[18] S.V. Rezvyakova, Hardiness of pear varieties derived from P. Ussuriensis, Bulletin of the Oryol State Agrarian University, 4, 13, 12-13 (2008).

[19] S.V. Rezvyakova, Adaptive potential of pear resistance to winter stress factors, Bulletin of the Oryol State Agrarian University, 1, 40, 84-88 (2013).

[20] E.N. Sedov, E.A. Dolmatov, Pear selection, VNIISPK, Oryol (1997).

[21] I.K. Khabirov, I.G. Asylbaev, I.M. Gabbasova, N.A. Lukmanov, A.N. Khasanov, Hydrothermal conditions - an important factor in the biologization of agriculture, Bulletin of the Irkutsk State Agricultural Academy, 65, 29-39 (2014).

[22] A.V. Shlyavas, A.A. Harchenko, E.G. Khudonogova, The study of the resistance of apple varieties of public selection to scab in the North-West of Russia, Bulletin of the Irkutsk State Agricultural Academy, 94, 62-71 (2019).
[23] Z. Ozherelieva, E. Sedov, Low temperature tolerance of apple cultivars of different ploidy at different times of the winter, Proceedings of the Latvian Academy of Sciences, Section B: Natural, Exact, and Applied Sciences (2017).

[24] E.N. Sedova, T.P. Ogoltsova (Ed.), Program and method of studying fruit, berry and nut crop varieties, VNIISPK, Oryol, 608 (1999).

[25] V.A. Dospekhov, Method of field experiments, Agropromizdat, Moscow (1985). 